\title{
Pregnancy-induced changes in substance $P$ and neurokinin 1 receptor (NK1-R) expression in the rat uterus
}

\author{
C. Schmidt, E. Lobos and K. Spanel-Borowski* \\ Institute of Anatomy, University of Leipzig, Liebigstrasse 13, Leipzig D-04103, Germany
}

Adrenergic nerve fibres of the mammalian uterus degenerate during pregnancy. The behaviour of peptidergic fibres, such as substance P-positive fibres and of its preferred neurokinin 1 receptor (NK1-R), is poorly studied in the pregnant rat uterus. The present study analysed the changes in substance $P$ immunoreactivity and in the expression of NK1-R protein in the uterus of non-pregnant, pregnant (days 7, 14 and 21) and postpartum rats (days 1, 8 and 22) by immunohistology, dot blot analysis and western blot analysis. In non-pregnant rats, substance P-positive fibres were localized to the myometrium; these fibres progressively disappeared during gestation and were almost absent at term (day 21). At day 22 post partum, substance Ppositive fibres had recovered to numbers comparable with those in the non-pregnant uterus. Dot blot analysis revealed a significant decrease in the immunoreactivity of substance
$P$ in the uterus at mid-pregnancy (day 14) and especially at term. Expression of the NK1-R protein showed a progressive increase throughout pregnancy reaching a peak on day 1 post partum; downregulation of NK1-R protein occurred on day 8 post partum. The low and high expressions of NK1-R protein were coincident with a large number of eosinophils and almost no eosinophils in the uterus at oestrus and at term, respectively. It was concluded that substance $P$ immunoreactivity is inversely correlated with NK1-R protein expression in the pregnant and postpartum uterus. The marked upregulation of NK1-R protein at term and after birth indicates that the NK1-R may be involved in the complex regulation of labour and postpartum physiology. However, it is likely that the NK1-protein is not involved in the recruitment of eosinophils into the uterus at oestrus.

\section{Introduction}

In general, tissues and organs undergoing hypertrophy and hyperplasia show growth of blood vessels and nerve fibres; however, the pregnant uterus is an exception. At term the pregnant uterus weighs surprisingly more than it does before pregnancy, even though the nerve fibres are no longer present in the myometrium (Alm and Lundberg, 1988; Haase et al., 1997; Zoubina and Smith, 2000). After parturition, the mammalian uterus is reinnervated. The physiological significance of uterine denervation may be one factor among others that support myometrial quiescence during growth of the fetus to prevent premature onset of labour. Furthermore, denervation of myometrial blood vessels impedes vasoconstriction and allows a regular placental blood flow. Although the denervation of adrenergic and cholinergic fibres in the non-pregnant and pregnant rat uterus has been reported by different groups (AIm and Lundberg, 1988; Haase et al., 1997; Zoubina and Smith, 2000), there are conflicting reports on the behaviour of the peptidergic system. However, substance

*Correspondence

Email: spanelb@medizin.uni-leipzig.de
$\mathrm{P}$ immunoreactivity appears to remain unchanged in the rat uterus during pregnancy (Traurig et al., 1984), whereas it has been found to increase by threefold, as measured by radioimmunoassay (Amira et al., 1995).

Retrograde tracing studies indicate that the perikarya of sensory intrauterine fibres are located in the upper lumbar ganglia and their axons in the superior ovarian nerve (Peters et al., 1987; Majewski et al., 1995; Papka et al., 1996). These fibres behave in a dual manner; they act as afferent fibres for transmission of nociception and as neuroeffectors by the local release of neuropeptides, such as substance $P$, a member of the tachykinin family (Hökfelt et al., 2001; Severini et al., 2002). Substance P acts via its preferred neurokinin 1 receptor (NK1-R). As the receptor is located on vascular cells, it induces a socalled neurogenic inflammation reaction, characterized by an increase in vascular permeability, the recruitment of leucocytes and vasodilatation (Schäffer et al., 1998; Lindsay De Vane, 2001). A significant increase in the content of NK1-R mRNA occurs during gestation in the rat uterus (Candenas et al., 2001). The functional activity of NK1-R localized on smooth muscle cells within the uterus has been verified using functional organ bath studies of contractility in the presence of selective NK1-R agonists and antagonists (Hamlin et al., 2000; Patak et al., 2000; Crane et al., 2002). However, 
evidence for the more significant occurrence of the NK1-R protein is lacking for the cyclic and pregnant uterus.

The rat uterus at oestrus has an abundance of eosinophils (Tchernitchin et al., 1976). These eosinophils disappear in the pregnant uterus and slowly reappear after term (Duchesne and Badia, 1992). Among other factors, recruitment of eosinophils depends on the presence of adhesion molecules, such as intercellular adhesion molecule and vascular cell adhesion molecule (VCAM) (Hogan and Foster, 1996). In vitro, VCAM is upregulated in endothelial cell cultures by a substance Pdependent stimulation of NK1-R causing strong adhesion of eosinophils (Dunzendorfer et al.,, 1998; Quinlan et al., 1999a,b). Therefore, it is of interest to compare the density of eosinophils, the amount of substance $\mathrm{P}$ immunoreactivity and expression of NK1-R protein in the non-pregnant, pregnant and postpartum rat uterus in a time course study.

The aims of the present study were to examine changes in substance P-positive intrauterine nerve fibres, to relate them to changes in substance $\mathrm{P}$ immunoreactivity by using dot blot analysis and to analyse changes in the expression of NK1-R protein by an immunoblot assay in the rat uterus throughout pregnancy and post partum compared with the non-pregnant uterus. Observations on the varying numbers of eosinophils are also included.

\section{Materials and Methods}

\section{Animals}

The experiments were approved by the local Institution for Ethical Guidelines of animals. Forty-nine female Wistar Fort rats were obtained from the breeding colony at the University of Leipzig. The rats had access to food and water ad libitum. Virgin sexually mature rats at oestrus, rats at days 7, 14 and 21 (term) of gestation and rats at days 1,8 and 22 post partum were analysed ( $n=7$ per group). Oestrus was determined by vaginal smears and mating was confirmed by the presence of spermatozoa in the vaginal smear. The rats were killed by an overdose of $\mathrm{CO}_{2}$. The uteri were removed and washed in sterile PBS ( $\mathrm{pH} 7.4)$; the uterine horns were dissected and removed from connective tissue, pups and placenta, and the uterine horns from the left-hand side were immediately stored at $-80^{\circ} \mathrm{C}$ until use.

\section{Immunohistology for substance $P$ and protein gene product 9.5 (PGP9.5), a general neuronal marker}

The uterine horns from the right-hand side of each group ( $n=7$ per group) were fixed in $4 \%(\mathrm{v} / \mathrm{v})$ PBSbuffered formaldehyde at room temperature $\left(21^{\circ} \mathrm{C}\right)$ overnight and embedded in paraffin wax. Implantation sites and interimplantation sites were studied separately. The uterine horns were cross-sectioned and then cut into serial sections $7 \mu \mathrm{m}$ in thickness and mounted on to object slides that had been coated with a paper glue. Deparaffinized tissue sections were treated with $3 \%(\mathrm{v} / \mathrm{v})$ $\mathrm{H}_{2} \mathrm{O}_{2}$ in $\mathrm{PBS}$ for 3 min to quench endogenous peroxidase activity, washed in PBS and Tris-buffered saline (TBS, $\mathrm{pH} 7.4$ ) (each buffer wash was for $2 \times 5 \mathrm{~min}$ ) and saturated with $1.5 \%$ normal goat serum (DAKO, Arhus) for $45 \mathrm{~min}$. The sections were incubated immediately with the polyclonal anti-substance $\mathrm{P}$ antibody (Biotrend Chemicals, Cologne, 1:2000 working dilution) in PBS containing $0.25 \%$ BSA (Sigma, St Louis, MO) in a humidified chamber at $4{ }^{\circ} \mathrm{C}$ overnight. Anti-substance $\mathrm{P}$ antibodies had been tested for specificity to substance $P$ and other tachykinins using purified substance $\mathrm{P}, \mathrm{NKA}$ and NKB peptides at various concentrations (range $10^{-6}$ to $10^{-9} \mathrm{~mol} \mathrm{I}^{-1}$ ). Dot blot analysis revealed antibodies that were specific for substance P. Negative controls were run with non-immune rabbit serum or PBS only.

After washing with buffer $\left(0.05\right.$ mol TBS ${ }^{-1}$ containing $0.12 \%(\mathrm{v} / \mathrm{v})$ Tween 20$)$ and with TBS only, each for $2 \times 5 \mathrm{~min}$, the sections were incubated with biotinylated goat anti-rabbit IgG (Vector Laboratories, Burlingame, CA) diluted at 1:200 in 0.05 mol TBS ${ }^{-1}$ containing 1\% normal goat serum for $30 \mathrm{~min}$ at room temperature. After rinsing, sections were incubated with avidin-biotinhorseradish peroxidase-labelled complex (VECTASTAIN, $A B C$ reagent, Vector Laboratories) for $30 \mathrm{~min}$. The complex was detected with substrate solution containing 29 mg 3-amino-9-ethylcarbazole (AEC, Sigma) dissolved in $100 \mathrm{ml}$ of 0.1 mol sodium acetate buffer $\mathrm{I}^{-1}, \mathrm{pH} 5.2$ containing $7.1 \mathrm{ml} \mathrm{N}, \mathrm{N}$-dimethylformamide and $0.03 \%$ $(\mathrm{v} / \mathrm{v}) \mathrm{H}_{2} \mathrm{O}_{2}$. The sections were treated with AEC for 15$20 \mathrm{~min}$ at $37^{\circ} \mathrm{C}$. After rinsing with distilled water and counterstaining with haematoxylin, the sections were embedded in water-soluble glycerine gelatine.

Another set of sections was similarly stained by using the rabbit polyclonal antibody against the PGP9.5 (Biotrend Chemicals) at a dilution of 1:4000. The PGP9.5 is considered as a pan-neuronal marker (Lundberg et al., 1988). ABC reagent complexes were detected by $0.02 \%$ $(\mathrm{w} / \mathrm{v}) 3^{\prime} 3^{\prime}$-diaminobenzidine (DAB, Aldrich, Basel) in TBS and containing $0.03 \% \mathrm{H}_{2} \mathrm{O}_{2}$ before use. Sections were embedded in Histokitt (Roth, Karlsruhe). Staining for substance P and PGP9.5 was repeated twice for the uterus of each group and was performed on independent days.

\section{Protein extraction}

The uterine horn from the left-hand side was minced with a pestle and mortar in liquid nitrogen. Powder was resuspended in $1 \mathrm{ml}$ ice-cold homogenization buffer (20.0 mmol Hepes I-1, $1.0 \mathrm{mmol}$ EDTA I ${ }^{-1}, 0.2 \mathrm{~mol}$ sucrose $\mathrm{I}^{-1}, 20.0 \mu \mathrm{g}$ soybean trypsin inhibitor $\mathrm{ml}^{-1}$, $20.0 \mu \mathrm{g}$ leupeptin $\mathrm{ml}^{-1}, 5.0 \mu \mathrm{g}$ pepstatin $\mathrm{A} \mathrm{ml}^{-1}$, $5.0 \mathrm{mmol}$ dithiothreitol $\mathrm{I}^{-1}, 5.0 \mu \mathrm{g} \mathrm{E}-64 \mathrm{ml}^{-1}, 5.0 \mu \mathrm{g}$ bestatin $\mathrm{ml}^{-1}, 5.0 \mu \mathrm{g}$ aprotinin $\mathrm{ml}^{-1}, 5.0 \mu \mathrm{g}$ antipain $\mathrm{ml}^{-1}$ 
and $0.1 \mathrm{mmol}$ equine chorionic gonadotrophin $\mathrm{I}^{-1}$ ) containing $1.66 \%(\mathrm{v} / \mathrm{v})$ SDS as described by Cellek et al. (1999). After homogenization by ultrasonification the samples were centrifuged twice at $16060 \mathrm{~g}$ for $15 \mathrm{~min}$ at $4{ }^{\circ} \mathrm{C}$. The supernatants were pooled and the total protein concentration determined using the protein assay based on bicinchoninic acid and BSA as a standard (BCAmethod, Pierce, Rockford, IL).

\section{Immuno-dot blot analysis}

Proteins extracted from the left-hand side of the uterine horns of different groups were blotted at various dilutions on to a nitrocellulose membrane (BA85, Schleicher and Schuell, Dassel) (Reibiger et al., 2001). Before blotting, the optimal protein concentration of the primary and secondary antibodies was determined. A specificity control was performed involving pre-adsorption of substance $\mathrm{P}$ antibodies with the peptide substance $\mathrm{P}(100 \mu \mathrm{mol}$ $\mathrm{I}^{-1}$ ) for $16 \mathrm{~h}$ at $4^{\circ} \mathrm{C}$ as well as the use of non-immune rabbit serum. A protein extract from rat cerebellum was used as a positive substance $\mathrm{P}$ immunoreactivity control. The membranes were saturated with $5 \%(\mathrm{v} / \mathrm{v})$ milk powder in wash buffer $(0.3 \%(\mathrm{v} / \mathrm{v})$ Tween 20, $0.05 \%(\mathrm{v} / \mathrm{v})$ Triton-X100 in PBS), followed by immediate incubation with the anti-substance P antibody (1:1000) in buffer with $0.5 \%$ BSA overnight at $4{ }^{\circ} \mathrm{C}$. After washing, the membranes were incubated with horseradish peroxidase-labelled anti-rabbit IgG (Vector Laboratories) at a dilution of 1:5000 for $90 \mathrm{~min}$. Immunolabelling was detected with the enhanced chemoluminescence kit (ECL, Amersham Biosciences UK Limited, Little Chalfont) followed by exposure of nitrocellulose to Hyperfilm $\mathrm{ECL}$. The densitometrical analysis of autoradiograms was done with the Alphalmager ${ }^{\mathrm{TM}} 2000$ program (Alpha Innotech Corp., San Leandro, CA). The data were normalized to the expression of glyceraldehyde 3phosphate dehydrogenase (GAPDH).

\section{Immunoblot analysis of NK1-R}

Constituent proteins from uterine preparations were resolved on $12.5 \%$ SDS-PAGE and western blot analysis was carried out as described by Gounni et al. (2001). Specific binding of the anti-NK1-R antibodies at a dilution of 1:15 000 (Biotrend Chemicals) to the blots was performed overnight. The membranes were washed $(6 \times 10 \mathrm{~min})$ and then incubated for $1 \mathrm{~h}$ with goat antirabbit antibody conjugated to horseradish peroxidase (Vector Laboratories, 1:5000). Immunolabelling was visualized with an ECL kit according to the manufacturer's instructions (Amersham). Exposed films were analysed as described above. Loading of equal total protein and the band densitometrical analysis were normalized using the expression of GAPDH.

\section{Number of eosinophils}

For each uterine horn, deparaffinized cross-sections were stained with Sirius red (Bayer $A B$, Leverkusen) solution as described by Bogomoletz (1980) and Reibiger and Spanel-Borowski (2000). Eosinophils with a distinctly red stained cytoplasm and a bilobed nucleus were counted under $\times 40$ magnification using an ocular grid of $0.05 \mathrm{~mm}^{2}$. Ten areas of the endometrium were examined starting close to the myometrium and evaluating the basal zone at regular intervals. The number of eosinophils was calculated per $\mathrm{mm}^{2}$.

\section{Statistical analysis}

Values are expressed as the mean \pm SEM and \pm SD, respectively. Statistical analysis was performed using StatView Version 5.01. Significant differences among all group means were assessed by the non-parametric Kruskal-Wallis test followed by the Mann-Witney U test. Differences with a $P$ value of $<0.01$ were considered significant.

\section{Results}

Pregnancy induced changes in the density of substance P-positive nerve fibres and PGP.9.5-positive fibres, as deduced from serial sections of the pregnant rat uterus in comparison with the non-pregnant and postpartum uterus. At oestrus, the density of the fibres was at its maximum (Fig. 1a,b). The nerve fibres entered the uterus from the mesometrial side together with blood vessels. Fibres were detected in close association with blood vessels in the stratum vasculare at the antimesometrial side. The fibres were distributed from the stratum vasculare between the inner and the outer myometrial layers and were often running parallel to the longitudinal axis of smooth muscle cells. There appeared to be fewer substance P-positive fibres than PGP9.5positive fibres. A decrease in substance P-positive fibres was detected on day 14 of gestation (data not shown). This diminished density of nerve fibres between the myometrial fibres paralleled the loss in PGP9.5-positive fibres. On day 21 of pregnancy, neither substance Ppositive nor PGP9.5-positive fibres were apparent at the anti-mesometrial side either at the implantation area or the interimplantation area as verified in whole cross-sections and serial sections (Fig. 1c,d). Some PGP9.5-positive fibres remained at the mesometrial entrance side, although clearly reduced in number. A remarkable reappearance of substance P-positive fibres in the uterus was observed after birth; the number and distribution pattern of substance P-positive nerve fibres were almost similar to those in the uterus by day 22 post partum (Fig. 1e). PGP9.5-positive fibres showed a similar pattern of distribution (Fig. 1f). The negative controls performed using serum from pre-immune rabbits did not 

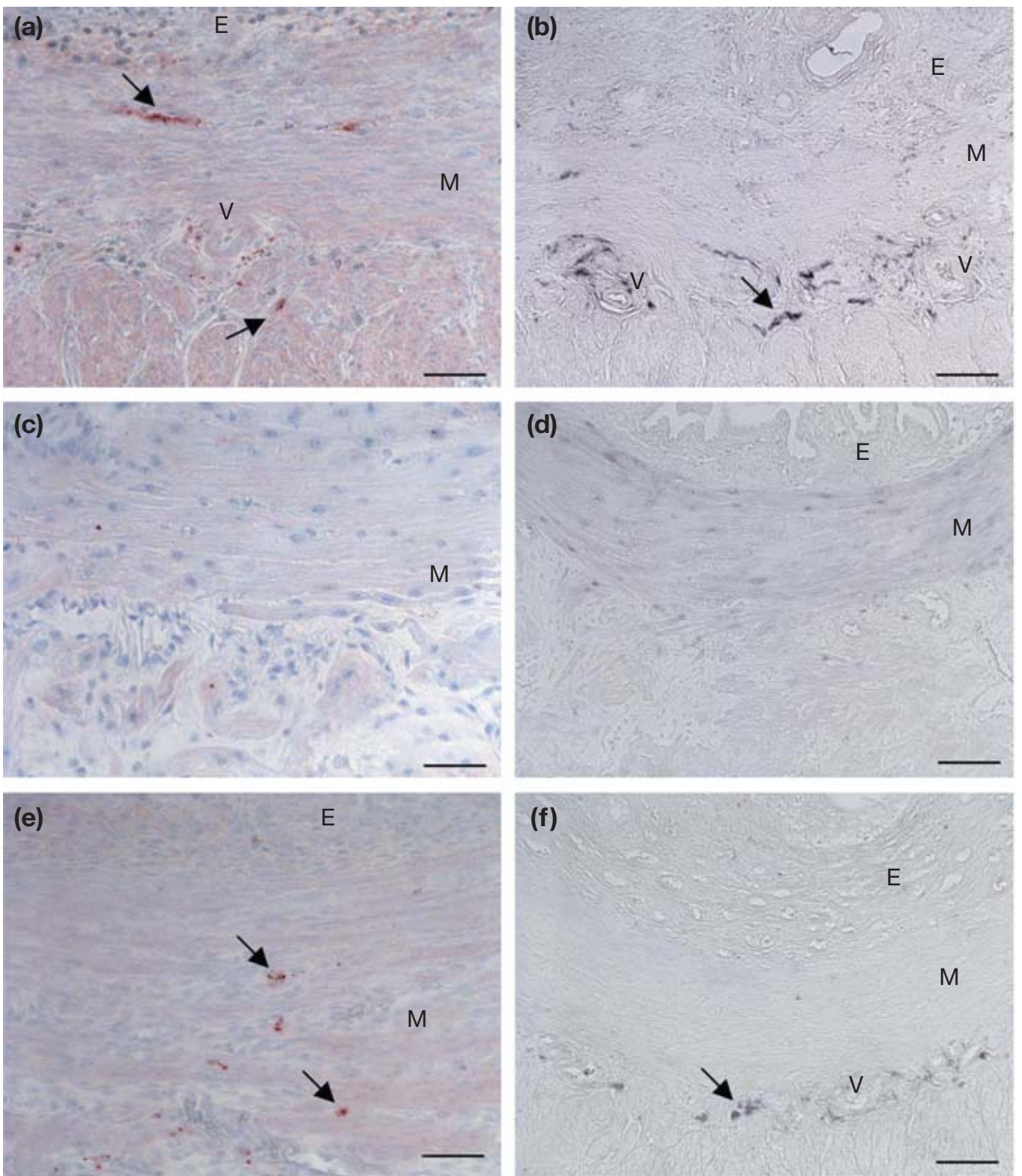

Fig. 1. Localization of substance P- and protein gene product 9.5 (PGP9.5)-positive nerve fibres in the non-pregnant, pregnant and postpartum rat uterus by indirect immunohistology. The tissue sections $(n=$ 7 per group) were processed twice and probed with a polyclonal rabbit antiserum to (a,c,e) substance $\mathrm{P}$ or to $(b, d, f)$ PGP9.5. (a) In the non-pregnant rat uterus, substance P-positive staining is present in nerve fibres of the myometrium both in the circular and longitudinal smooth muscle layers (arrows). A positive response appears close to blood vessels in the stratum vasculare. (b) In the non-pregnant uterus, positive fibres are distinctly located with the panneuronal marker PGP9.5. (c,d) Fibres are prominent in the stratum vasculare. On day 21 of gestation, note absence of substance P-positive nerve fibres in (c) and of PGP9.5 positive fibres in (d). (e,f) In the postpartum uterus on day 22, both the substance P-positive fibres (arrows in e) and PGP9.5-positive fibres (arrow in $\mathrm{f}$ ) reappear. E: endometrium, M: myometrium, V: blood vessel. Scale bars represent $(\mathrm{a}, \mathrm{c}, \mathrm{e}) 50 \mu \mathrm{m}$ and $(\mathrm{b}, \mathrm{d}, \mathrm{f}) 100 \mu \mathrm{m}$.

demonstrate any recognition of similar structures (data not shown). These results give clear evidence that the presence of substance P-positive nerve fibres is distinctly modulated in the myometrium during gestation and after parturition.
Semi-quantitative analysis to determine substance $P$ immunoreactivity in the rat uterus during gestation and post partum was carried out by dot-blot analysis (Fig. 2). Densitometric examination revealed that the immunoreactivity of substance $P$ in the uterus from virgin and 


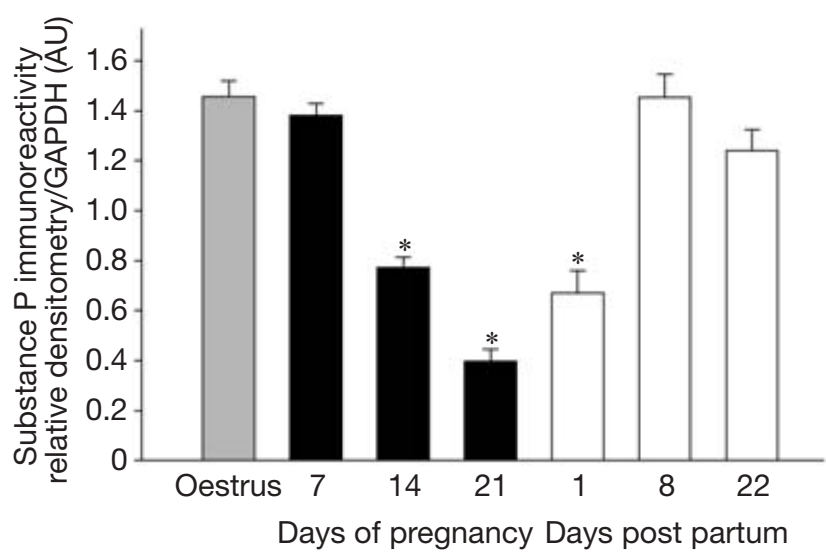

Fig. 2. Densitometric analysis of changes in substance $P$ immunoreactivity in the rat uterus during pregnancy (days 7, 14 and 21, - a) and after parturition (days 1, 8 and 22, $\square$ ). Equal amounts of uterine proteins $(5 \mu \mathrm{g})$ from non-pregnant, pregnant and postpartum rats were subjected to dot-blot analysis. Signals have been normalized to glyceraldehyde 3-phosphate dehydrogenase (GAPDH) levels and are expressed as arbitrary units $(A U)$. The histograms represent mean \pm SEM from five to seven different rats in each group. ${ }^{*} P<0.01$ versus the other days. The data are representative of three separate experiments.

early pregnancy (day 7) exhibited approximately equal intensities in the dot-blot assay with no significant differences. In contrast, significant differences in substance $P$ immunoreactivity were observed on days 14 and 21 (full term) of gestation in comparison with the non-pregnant uterus $(P<0.001)$. The immunoreactivity of substance $P$ in the uterus remained low after parturition and was still significantly decreased when compared with that in the non-pregnant uterus $(P<0.001)$, but a rapid recovery in substance $P$ immunoreactivity occurred from day 8 post partum onwards and was significantly different from the expression during pregnancy and on day 1 post partum $(P<0.001)$. Immunoblot analysis with antiNK1-R antibody was performed to examine NK1-R expression at the protein level in the non-pregnant, pregnant and postpartum uterus (Fig. 3a). The antibody against the NK1-R specifically recognized a protein migrating at approximately $50 \mathrm{kDa}$ that corresponds to the known molecular mass of the rat NK1-R protein (Hershey and Krause, 1990). This protein did not react with pre-immune serum. Compared with the rat uterus at oestrus, a clear upregulation of NK1-R protein expression was demonstrated with increasing days of pregnancy and on day 1 post partum. Densitometric analysis of the signals after normalization to GAPDH levels (Fig. 3b) demonstrated a progressive increase in NK1-R protein expression on days 7, 14 and 21 of gestation $(P<0.01$ for all compared with the oestrous uterus). The amounts of NK1-R protein in the pregnant uterus were about 1.7 to 2.0-fold higher than the amounts of NK1-R protein in the non-pregnant uterus. Unexpectedly, densitometric analysis revealed that NK1-R protein content was the (a)

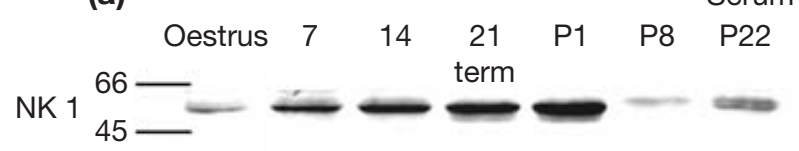

(b)

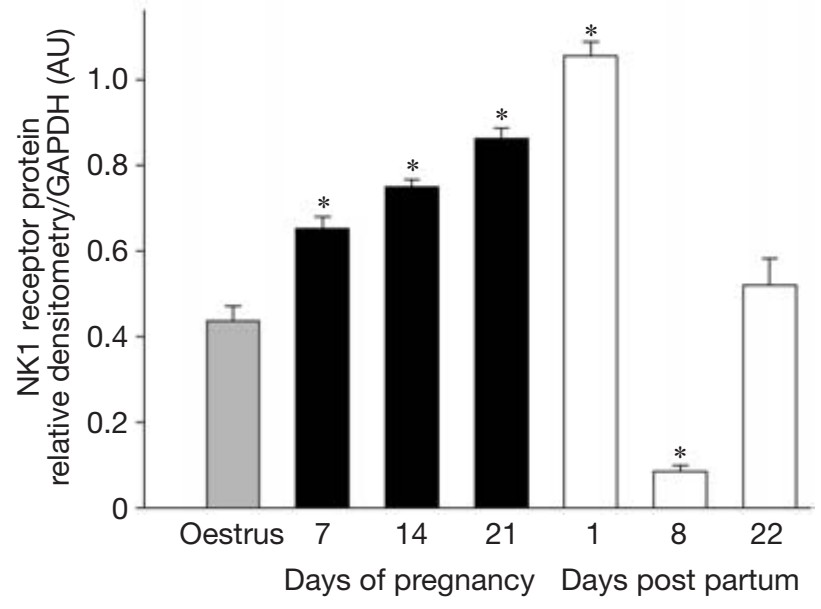

Fig. 3. (a) Immunoblot analysis of the expression of neurokinin 1 receptor $(\mathrm{NK} 1-\mathrm{R})$ protein in the rat uterus during pregnancy and after parturition. Similar amounts of proteins $(30 \mu \mathrm{g})$ from uterine extracts of individual samples on various days of pregnancy or after parturition were separated by $12.5 \%$ SDS-PAGE and immunoblotted using the anti-NK1-R antibody. Lanes are indicated from left to right: oestrus, days 7, 14 and 21 (term) of pregnancy, days 1,8 and 22 post partum, non-immune serum. The relative position of the molecular mass markers in $\mathrm{kDa}$ is indicated on the left. The nitrocellulose membranes were also probed with anti-glyceraldehyde 3-phosphate dehydrogenase (GAPDH) as an indicator of equal loading (data not shown). (b) Densitometric analysis of NK1-R protein expression during pregnancy (days 7, 14 and 21, $\mathbf{a}$ ) and after parturition (days 1, 8 and 22, $\square$ ). Signals were normalized to GAPDH levels and expressed as arbitrary units $(A U)$. Histograms represent the mean \pm SEM from four to five different rats in each group. $* P<0.01$ versus oestrus and day 22 post partum.

highest on day 1 post partum showing a 2.4-fold increase when compared with the non-pregnant uterus. The expression of NK1-R was at its lowest on day 8 post partum.

Eosinophils populated the cyclic uterus more densely in the basal zone of the endometrium than in the myometrium (Fig. 4). They were undetectable in uterus at mid-pregnancy and at term. On day 1 post partum, eosinophils started to migrate into the postpartum uterus, yet on day 22 the number remained below the number detected in the cyclic uterus (Fig. 5).

\section{Discussion}

Studies on substance $\mathrm{P}$ immunoreactivity in the rat uterus throughout pregnancy are contradictory. Some 

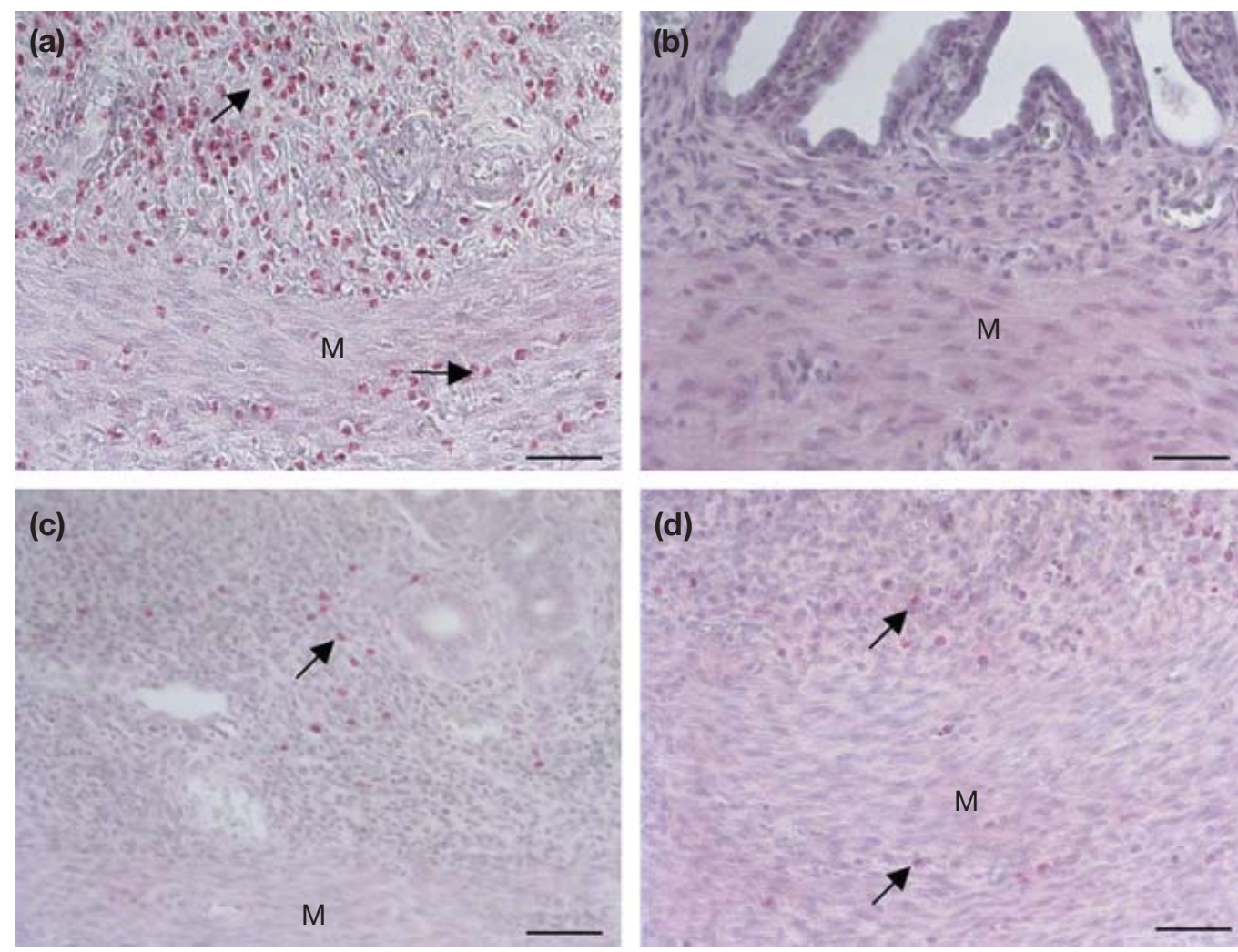

Fig. 4. Eosinophils (arrows) are stained with the Sirius red solution and located in the rat uterus. (a) Oestrous stage, (b) at term, that is day 21 of pregnancy, (c) day 8 post partum and (d) day 22 post partum. M: myometrium. Scale bars represent $50 \mu \mathrm{m}$.

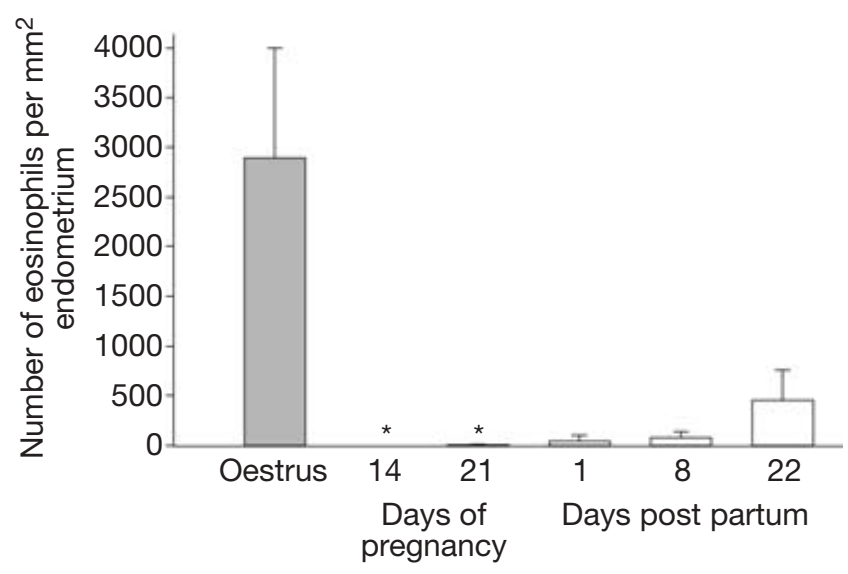

Fig. 5. Number of eosinophils per $\mathrm{mm}^{2}$ of rat endometrium adjacent to the myometrium at oestrus, on days 14 and 21 of pregnancy, and on days 1,8 and 22 post partum. Histograms represent the mean $\pm S D$ from six different rats in each group. $* P<0.001$ compared with oestrus.

studies report no change, whereas others report an increase in substance $\mathrm{P}$ immunoreactivity (Traurig et al., 1984; Amira et al., 1995). The normal and increased substance $\mathrm{P}$ immunoreactivity may be explained by different sensitivities of two different immunological assays. The assumption is that the substance P-positive fibres remain stable intrauterine elements despite the presence of high concentrations of sex steroids or may even increase in density in the pregnant rat uterus. This assumption is not in agreement with the results of the present study, which clearly show the disappearance of myometrial and perivascular substance P-positive fibres during pregnancy. Immuno-dot blot analysis also depicts a decrease in substance $P$ immunoreactivity during pregnancy. The immunoreactivity of substance $P$ in the present study is related per mg protein, because there is an uneven nerve fibre distribution between regions of the rat uterus (Richeri et al., 2002). For this reason, substance $\mathrm{P}$ immunoreactivity that has been obtained from a small uterine portion cannot be translated to total uterine horn. The decrease in peptidergic nerve fibres in the pregnant uterus observed in the present study may be explained by the presence of serum oestrogens at increased concentrations at mid- and late pregnancy. This assumption is supported by the finding that chronic oestrogen treatment causes a complete loss of sympathetic nerve fibres in the prepuberal rat uterus (Brauer et al., 1995). The high oestrogen concentrations of pregnancy may affect dorsal root ganglion neurones which express both mRNA and protein of oestrogen receptor- $\alpha$ and - $\beta$ (Papka et al., 2001). Furthermore, the 
growing fetus may cause a stretch-induced intrauterine nerve fibre degeneration and be responsible for the retraction of axon terminals (Lundberg et al., 1989).

The present study demonstrates a significant variation of substance $\mathrm{P}$ immunoreactivity and changes in the occurrence of NK1 protein in the rat uterus during gestation. It is evident that the decrease in substance $\mathrm{P}$ immunoreactivity in the pregnant rat uterus is negatively correlated with NK1-R protein synthesis during pregnancy, at term or on day 1 post partum. The reverse is stated on day 8 post partum when substance $P$ immunoreactivity reappears and the lowest NK1-R protein expression is seen. So far only the functional activity of tachykinin receptors has been investigated by testing myometrial contractions under the treatment of receptor agonist and antagonist either in rat uterus (Pinto et al., 1999; Hamlin et al., 2000; Candenas et al., 2001; Crane et al., 2002) or in human uterus (Patak et al., 2000).

Pinto et al. (1999) reported that the mRNA content of NK1-R is upregulated by oestrogens in the uterus of ovariectomized rats. Little is known about the mechanism by which NK1-R protein synthesis is increased in the uterus at term or on day 1 post partum. This observation may be explained by basic sensitization, that is a moderate receptor internalization because the local amount of substance $\mathrm{P}$ and, thus, substance $\mathrm{P}$ binding is low. In comparison, sites with neurogenic inflammation and a high amount of substance $\mathrm{P}$ rapidly internalize the receptor-ligand complex to limit the inflammatory response (Bowden et al., 1994). Furthermore, the high NK1-R protein synthesis observed here may be influenced by interferon- $\gamma$ secreted from the pregnancyassociated natural killer cells (Askar and Croy, 2001). This cytokine is able to increase the synthesis of the NK1-R protein on peritoneal macrophages (Marriott and Bost, 2000). Thus, the pregnant rat uterus may become a useful animal model to get new insights into the regulation of NK1-R protein synthesis.

The demand for myometrial contraction at term depends on a high density of gap junctions which transform the myometrium into a functional syncytium. At the onset of labour, connexin 43, the major myometrial gap junction protein, is upregulated by receptors, for example oxytocin, prostaglandins and endothelin 1 (Carbillon et al., 2001). The high amount of the NK1-R protein at term and on day 1 post partum observed in the present study indicates communication between NK1-R protein synthesis and gap junction formation in support of myometrial contractions at term. If this hypothesis is correct, other tachykinins rather than substance P might interact with NK1-R, because the tachykinin system is very redundant (Hökfelt et al., 2001; Severini et al., 2002).

One of the substance P-dependent functions corresponds to the NK1-R mediated upregulation of VCAM expression on cultured endothelial cells and to stimulat- ory chemotactic effect on eosinophil migration in vitro (Dunzendorfer et al., 1998; Quinlan et al., 1999a,b). Here the NK1-R protein content is very low in the nonpregnant uterus, which is densely populated by eosinophils. Yet the receptor increases in the pregnant rat uterus when eosinophils have disappeared. This indicates that NK1-R is not involved in eosinophil recruitment into the rat uterus. Oestrogens remain as the major candidates; they greatly modulate endothelial cell adhesion molecules (Cid et al., 2002) and are known to cause the recruitment of eosinophils into the uterus of ovariectomized rats (Tchernitchin et al., 1976; Lee et al., 1989).

This research was supported by the Bundesministerium für Bildung und Forschung (BMBF), Interdisciplinary Center of Clinical Research (IZKF), at the University of Leipzig, grant no. 01 K69504/2, B6 as well as by the Deutsche Forschungsgemeinschaft (DFG), grant no. Sp 232/7-1.

\section{References}

Alm P and Lundberg LM (1988) Co-existence and origin of peptidergic and adrenergic nerves in the guinea pig uterus. Retrograde tracing and immunocytochemistry, effects of chemical sympathectomy, capsaicin treatment and pregnancy Cell and Tissue Research 254 517-530

Amira S, Morrison JFB and Rayfield KM (1995) The effects of pregnancy and parturition on the substance $P$ content of the rat uterus: uterine growth is accompanied by hypertrophy of its afferent innervation Experimental Physiology 80 645-650

Ashkar AA and Croy BA (2001) Functions of uterine natural killer cells are mediated by interferon- $\gamma$ production during murine pregnancy Seminars in Immunology 13 235-241

Bogomoletz W (1980) Avantages de la coloration par le rouge sirus de I'amyloide et des eosinophiles Archives $d^{\prime}$ Anatomie et de Cytology Pathologiques 28 252-253

Bowden J, Garland AM, Baluk P, Lefevre P, Grady EF, Vigna SR and McDonald DM (1994) Direct observation of substance-P induced internalization of neurokinin 1 (NK1) receptors at sites of inflammation Proceedings National Academy of Sciences 91 8964-8968

Brauer MM, Corbacho AM and Burnstock G (1995) Effects of chronic and acute oestrogen treatment on the developing noradrenalin-containing nerves of the rat uterus International Journal of Developmental Neuroscience 13 791-798

Candenas ML, Magraner J, Armesto CP, Anselmi E, Nieto PM, Martin JD, Advenier C and Pinto FM (2001) Changes in the expression of tachykinin receptors in the rat uterus during the course of pregnancy Biology of Reproduction 65 538-543

Carbillon L, Seince N and Uzan M (2001) Myometrial maturation and labour Annals of Medicine 33 571-578

Cellek S, Rodrigo J, Lobos E, Fernandez P, Serrano J and Moncada S (1999) Selective nitrergic neurodegeneration in diabetes mellitus - a nitric oxide-dependent phenomenon British Journal of Pharmacology 128 1804-1812

Cid MC, Schnaper HW and Kleinmann HK (2002) Estrogens and the vascular endothelium Annals of the New York Academy of Sciences 966 143-157

Crane LH, Williams MJ, Nimmo AJ and Hamlin GP (2002) Estrogendependent regulation of neurokinin 3 receptor-mediated uterine contractility in the rat Biology of Reproduction 67 1480-1487

Duchesne MJ and Badia E (1992) Immunohistochemical localization of the eosinophil major basic protein in the uterus horn and cervix of the rat at term and after parturition Cell Tissue Research 270 79-86

Dunzendorfer S, Meierhofer C and Wiedemann CJ (1998) Signaling in neuropeptide-induced migration of human eosinophils Journal of Leukocyte Biology 64 828-834 
Gounni AS, Spanel-Borowski K, Palacios M, Heusser C, Moncada S and Lobos E (2001) Pulmonary inflammation induced by a recombinant Brugia malayi gamma-glutamyl transpeptidase homolog: involvement of humoral autoimmune responses Molecular Medicine 7344 354

Haase EB, Buchman J, Tietz AE and Schramm LP (1997) Pregnancy-induced uterine neuronal degeneration in the rat Cell and Tissue Research $\mathbf{2 8 8}$ 293-306

Hamlin GP, Williams MJ, Nimmo AJ and Crane LH (2000) Hormonal variation of rat uterine contractile responsiveness to selective neurokinin receptor agonists Biology of Reproduction 62 1661-1666

Hershey AD and Krause JE (1990) Molecular characterization of a functional cDNA encoding the rat substance $\mathrm{P}$ receptor Science 247958 962

Hogan SP and Foster PS (1996) Cellular and molecular mechanisms involved in the regulation of eosinophil trafficking in vivo. Medicinal Research Reviews 16 407-432

Hökfelt T, Pernow B and Wahren J (2001) Substance P, a pioneer amongst neuropeptides Journal of Internal Medicine 249 27-40

Lee YH, Howe RS, Sha S-J, Teuscher C, Sheehan DM and Lyttle CR (1989) Estrogen regulation of an eosinophil chemotactic factor in the immature rat uterus Endocrinology 125 3022-3028

Lindsay DeVane C (2001) Substance P, a new era, a new role Pharmacotherapy 21 1061-1069

Lundberg LM, Alm P, Wharton J and Polak JM (1988) Protein gene product 9.5 (PGP 9.5). A new neuronal marker visualizing the whole uterine innervation and pregnancy-induced and developmental changes in the guinea pig Histochemistry 90 9-17

Lundberg LM, Alm P and Thorbert G (1989) Local mechanical effects and humoral factors evoke degeneration of guinea pig uterine innervation Acta Obstetrica and Gynecologica Scandinavia 68 487-496

Majewski M, Sienkiewicz W, Kaleczyc J, Mayer B, Czaja K and Lakomy M (1995) The distribution and co-localization of immunoreactivity to nitric oxide synthase, vasoactive intestinal polypeptide and substane $P$ within nerve fibers supplying bovine and porcine female genital organs Cell and Tissue Research 281 445-464

Marriott I and Bost KL (2000) IL-4 and IFN-gamma upregulate substance $\mathrm{P}$ receptor expression in murine peritoneal macrophages Immunology 165 182-191

Papka RE, Thompson BD and Schmidt HH (1996) Identification of uterinerelated sympathetic neurons in the rat inferior mesenteric ganglion: neurotransmitter content and afferent input Journal of the Autonomic Nervous System 59 51-59

Papka RE, Storey-Workley M, Shughrue PJ, Merchenhaler I, Collins JJ, Usip S, Saunders PTK and Shupnik M (2001) Estrogen receptor- $\alpha$ and $-\beta$ immunoreactivity and mRNA in neurons of sensory and autonomic ganglia and spinal cord Cell and Tissue Research 304 193-214

Patak EN, Ziccone S, Story ME, Fleming AJ, Lilley A and Pennefather JN (2000) Activation of neurokinin $\mathrm{NK}_{2}$ receptors by tachykinin peptides causes contraction of uterus in pregnant women near term Molecular Human Reproduction 6 549-554
Peters LC, Kristal MB and Komisaruk BR (1987) Sensory innervation of the external and internal genitalia of the female rat Brain Research $\mathbf{4 0 8}$ 199-204

Pinto FM, Armesto CP, Magraner J, Trujillo M, Martin JD and Canden ML (1999) Tachykinin receptor and neutral endopeptidase gene expression in the rat uterus: characterization and regulation in response to ovarian steroid treatment Endocrinology 140 2526-2532

Quinlan KL, Song I-S, Naik SM, Letran EL, Olerud JE, Bunnet NW, Armstrong CA, Caughmann SW and Ansel JC (1999a) VCAM-1 Expression on human dermal microvascular endothelial cells is directly and specifically up-regulated by substance P Journal of Immunology 162 1656-1661

Quinlan KL, Naik SM, Cannon G, Armstrong CA, Bunnett NW, Ansel JC and Caughman SW (1999b) Substance P activates coincident NF-AT- and NF-кB-dependent adhesion molecule gene expression in microvascular endothelial cells through intracellular calcium mobilization Journal of Immunology 163 5656-5665

Reibiger I and Spanel-Borowski K (2000) Difference in localization of eosinophils and mast cells in the bovine ovary Journal of Reproduction 118 243-249

Reibiger I, Aust G, Tscheudschilsuren G, Beyer R, Gebhardts C and SpanelBorowski K (2001) The expression of substance P and its neurokinin-1 receptor mRNA in the bovine corpus luteum of early developmental stage Neuroscience Letters 299 49-52

Richeri A, Viettro L, Chavez-Genaro R, Burnstock G, Cowen T and Brauer MM (2002) Effects of infantile/prepuberal chronic estrogen treatment and chemical sympathectomy with guanethidine on developing cholinergic nerves of the rat uterus Journal of Histochemistry and Cytochemistry $\mathbf{5 0}$ 839-850

Schäffer M, Beiter T, Becker HD and Hunt TK (1998) Neuropeptides. Mediators of inflammation and tissue repair Archives of Surgery 133 1107-1116

Severini C, Improta G, Falconieri-Erspamer G, Salvadori S and Erspamer V (2002) The tachykinin peptide family Pharmacological Reviews $\mathbf{5 4}$ 285-322

Tchernitchin X, Tchernitchin A and Galand P (1976) Dynamics of eosinophils in the uterus after oestrogen administration Differentiation 5 151-154

Traurig H, Saria A and Lembeck F (1984) Substance P in primary afferent neurons on the female reproductive system Naunyn Schmiedebergs Archives of Pharmacology 326 343-346

Zoubina EV and Smith PG (2000) Axonal degeneration and regeneration in rat uterus during the estrous cycle Automic Neuroscience 84 176-185

Received 23 May 2003.

First decision 2 July 2003.

Revised manuscript received 7 July 2003.

Accepted 10 July 2003 